This is the author's final, peer-reviewed manuscript as accepted for publication. The publisher-formatted version may be available through the publisher's web site or your institution's library.

\title{
Growing a New Generation of Music Teachers
}

Frederick Burrack

Frederick Burrack is an associate professor of music education at Kansas State

University in Manhattan. He can be reached at fburrack@ksu.edu

How to cite this manuscript (APA format)

If you make reference to this version of the manuscript, use the following citation format:

Burrack, F. (2009). Growing a New Generation of Music Teachers. Retrieved from http://krex.ksu.edu

\section{Published Version Information}

Citation: Burrack, F. (2009). Growing a New Generation of Music Teachers. Music Educators Journal Volume 96, Issue 2, pages 40-44.

Copyright: Copyright @ 2009 MENC: The National Association for Music Education

Digital Object Identifier (DOI): DOI: $10.2307 / 3399802$

Publisher's Link: http://online.sagepub.com/ 


\title{
Growing a New Generation of Music Teachers
}

\author{
By Frederick Burrack
}

Frederick Burrack is an associate professor of music education at Kansas State University in Manhattan. He can be reached at fburrack@ksu.edu

[ABSTRACT] At a time when many veteran music teachers are retiring, an apprenticeship program can help high school students consider a music career and offers them increased chances of success in college and beyond. This article offers information about the Music Teacher Apprenticeship Program made available through Kansas State University Music Education Department.

In many parts of the United States, there is a growing shortage of music teachers to take the place of the retiring teachers. ${ }^{1}$ This is most evident in rural areas. If music teachers are not available to fill openings, music positions are sometimes combined, spreading music teachers too thin and requiring them to possess multiple music proficiencies. Sometimes the only option for rural schools is to hire teachers on temporary licensure who have not achieved music certification. In this supply and demand situation, if the result is providing music education that does not succeed in developing a skilled and knowledgeable culture as defined by $\mathrm{MENC}^{2}$; this cultivates a musically undereducated generation being modeled a less-than- desirable value for music.

\section{Solutions?}

Is there anything we can do about this problem? This issue necessitates increasing the number of students interested in becoming music teachers and focusing careers in difficult to fill positions. Looking more deeply into the reasons students choose to become music teachers, a 2001 survey of MENC collegiate members revealed that a majority of music education majors decided to become music teachers while still in high school and 14 percent during their elementary or middle school years. ${ }^{3}$

Bergee's findings showed what influenced these college students to become music educators:

- The most influential person was their high school music teacher.

- The most influential experiences were high school instrumental and choral ensembles.

- The most influential events were participating in solo/ensemble festivals and honor groups such as all-states. ${ }^{4}$

With these considerations in mind, the Kansas Music Educators Association is implementing the Music Teacher Apprenticeship Program, designed around an 
apprenticeship program implemented at Carroll High School, Carroll, Iowa, and another in Huntington Park High School, Huntington Park, California, in the 1990s. ${ }^{5}$

\section{Apprenticeships}

The goal of the Music Teacher Apprenticeship Program is to incite an interest in pursuing the music teaching professions and develop well-rounded musicians who would be capable of successfully completing a degree in music education. The objectives are that each student involved in the program will:

- Meet advanced performance standards in one instrument or voice.

- Meet proficiency in music history and music theory as described by Advanced Placement exams.

- Be able to play piano at a late beginner or early intermediate level.

- Meet university entry-level proficiency for sight-singing and interval singing.

- Have working knowledge of music technology including the use of music printing software, music sequencing, CD-ROM programs, and multimedia authoring such as Web pages or PowerPoint.

- Have acquired beginning-level teaching skills from tutoring other music students.

- Have acquired beginning-level conducting skills from student directing experiences.

- Have experienced administrative tasks required of music teachers.

The program is divided into three major segments that include: advanced musical achievement; apprenticeship; tutoring; and conducting experiences. Each participating school does what is within their capability, timeframe, and resources.

\section{The Sophomore Year}

During the sophomore year of high school, students who show interest in music and/or teaching as a career or have obvious leadership abilities are encouraged to participate in the Music Teacher Apprenticeship Program.

1. An introduction to music theory course is taught beginning with a review of music fundamentals leading to aural and visual interval recognition and chord progression identification.

2. Each student is assigned one younger student to teach weekly lesson over a semester's time. They are expected to maintain a notebook of lesson content, 
progress notes, and reflections on their teaching experience.

3. Each student is encouraged to take private piano or a piano class.

4. Students are required to prepare a solo for the state solo festival and participate in a large ensemble.

\section{The Junior Year}

During the junior year of high school, the students involved in the program:

1. Continue in a second level of music theory including four-part voice leading, instrument transposition, and harmonic compositional devices. Ear training includes simple harmonic progression identification as well as interval and chord inversions. Historical background and examples are provided associated with the theory learning. Student compositions are performed on an annual student composition recital. Music writing/printing software is introduced and expected for assignments.

2. Teaching lessons to younger students are continued, often teaching a different grade level of student than the previous year.

3. Students are assigned a music teacher in the district to shadow one or two days a week during a study hall. The student observes classes, participates in administrative tasks, and leads sectional rehearsals when needed.

4. Each student is encouraged to take private piano or piano class.

5. Students are required to prepare a solo for the state solo festival and participate in a large ensemble was required.

\section{The Senior Year}

During the senior year of high school, the students involved in the program:

1. Continue in a third level of music theory that introduces jazz harmonies and compositional techniques. Harmonic progression identification is expected for aural training. Student compositions are performed on an annual student composition recital or on a larger concert if the ensemble for the piece is a full band, jazz band, or choir. Music sequencing programs and CD-ROM programs relevant to advanced training are introduced and used for ear training, music history and theory exams.

2. Teaching lessons to younger students are continued as in the previous year. 
3. Students are taught basic conducting techniques and provided an ensemble to teach/conduct a piece for performance at a concert. They become the student conductor for the semester.

4. Each student is encouraged to take private piano or piano class. A typical piano proficiency exam is provided experience for university expectations.

5. Students are required to prepare a solo for the state solo festival and expected to perform on a selected solo on a recital. Some student can choose to perform all of the selections learned through high school on a solo recital for parents and friends. These recitals can be scheduled in the spring, primarily during graduation weekend for relatives who may be visiting.

6. Participation in a large ensemble was required.

7. A portfolio including summaries of experiences through the entire program, examples of their progress, and an essay on what they learned about teaching music in schools is presented.

\section{Implementing the Program}

The music teachers often teach a theory/history courses as part of their regular class load but can be offered as independent study. Individualized instruction is provided for conducting lessons and much of the technology. Younger students being tutored are selected from the high school music classes or from local elementary and middle schools. The form found in Figure 1 is completed by the apprentice for each lesson and kept in a folder to be used in their portfolio.

At the end of each semester, the student turns the completed logs to the teacher with a reflection of their overall experience as a teacher. This reflection includes what they learned and goals for improvement as a teacher. In addition to learning and experience basic teaching techniques, their own performing skills are strengthened. The ensembles benefited from the lesson program as individual students' proficiencies are enhanced.

The shadowing and directing provide the apprentices with valuable experience that prepares them for majoring in music education. This component also helps the director by providing assistance with administrative tasks, sectionals, and other instructional duties involved in teaching. When students are involved in the tutoring, shadowing and directing components, the principal must be made aware and approve of this type of student involvement. Several permission forms are also important: a parent consent for travel if the student was in a different school, a cooperating teacher agreement form so the teachers involved are fully aware of and agree to their responsibility, agreement forms for administrators supporting the activities involved, a tutoring assignment plan so the apprentice is fully aware of their responsibilities as a tutor, and a tutor evaluation form to assess the achievements of the apprentice. (samples of these forms can be found at the following Web link http://www.k-state.edu/musiceducation/apprenticeship/forms.htm.

The inclusion of private lessons for the apprentices is probably one of the most important parts of the program to enhance individual performance proficiency. In some 
schools, every student in the ensemble class is provided private or group lessons. Those in the apprenticeship program should be assured private lessons, usually longer in length. These students can take private lessons outside the school as well. The senior recital involves preparing two selections of contrasting styles and appropriate for use in college scholarship auditions.

Students who complete the similar programs offered at their high schools are "looked upon favorably by colleges in the admission process." achieved at higher levels during the first semester or entire first year in comparison to fellow students. Because of the in-depth training involved in the apprenticeship program, students obtain the skills and knowledge needed to succeed in college music education courses. University professors have been impressed with portfolios that have been produced in participating programs. These were often shared at scholarship auditions or application meetings.

At the Carroll High School, this program persuaded administration to offer the music theory/history courses for full credit. The counseling staff chose to include the Apprenticeship Program in career placement activities. Such a program would be a good way to initiate a Tri-M chapter in your school. Kansas State University hopes that such a program in Kansas will encourage a greater number of students to choose music education as a future profession. If students from small towns become involved and choose music education, they may choose to teach in a small school program for their career creating a more stable music education in these schools than often experienced.

More information about the entire Apprenticeship Program can be found at http://www.k-state.edu/musiceducation/apprenticeship/index.htm. The Kansas State University music education department would like to assist with the implementation of the program into schools and follow students in and beyond the experiences to document the effect on their decisions to become music teachers, see if the program can help retain teachers in rural areas, and to continually enhance the program.

\section{Notes}

1. Hill Jr., Willie. (2003) The teacher shortage and policy. Music Educators Journal, 89(4), 6-7.

2. Janice Killian and Vicki Baker, "The Effect of Personal and Situational Factors in the Attrition and Retention of Texas Music Educators," Journal of Music Teacher Education 16, no 1, 2006: 42.

3. Martin Bergee, 'Influences on College Students' Decision to Become a Music Educator,” 2001. Retrieved August 7, 2007 from MENC: The National

Association for Music Education Web site: http://www.menc.org/networks/rnc/Bergee-Report.html

4. Ibid

5. Edward Trimis, "Building a High School Music Major Program,” Music Educators Journal 84, no 5, 19-23.

6. Trimis, p. 23. 


\section{Figure 1: Teaching Log}

Teacher Name

Date

Student Name Instrument

Selected Exercises and Description of Teaching Plan

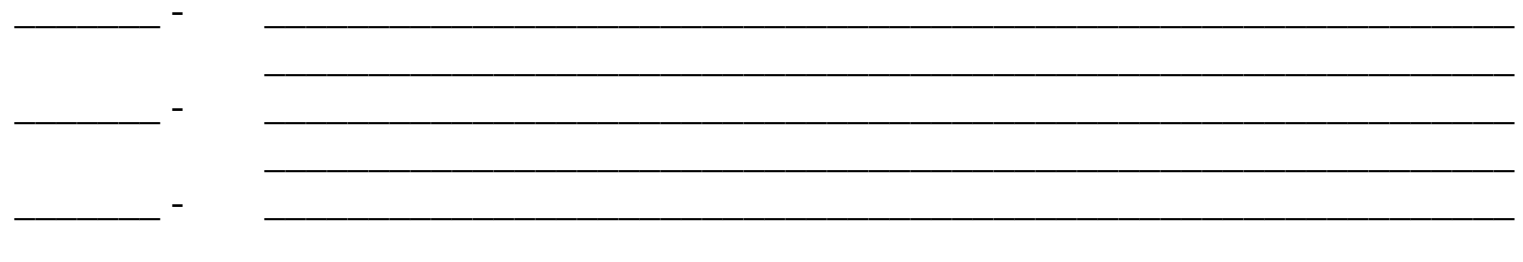

Assessment of Student Performance and Goals Provided for Improvement (tone quality, rhythm, fingering accuracy, posture, musicality, etc)

Assessment of Your Teaching and Goals for Improvement: 